Комментарий к статье Д.В. Чугаева с соавторами

«Одномыщелковое латеральное эндопротезирование в структуре современной артропластики коленного сустава: «горе от ума» или оптимальное решение?»

Травматология и ортопедия России. 2020;26(3):34-48.

\title{
Comment on the Article by D.V. Chugaev et al. "Lateral Unicompartmental Knee Arthroplasty in Structure of Modern Knee Replacement: Is It "Woe From Wit” or a Viable Go-To Method?"
}

Traumatology and Orthopedics of Russia. 2020;26(3):34-48.

На написание этого комментария нас подтолкнула фраза авторов статьи об отсутствии отечественных данных по эпидемиологии одномыщелкового эндопротезирования большеберцовой кости и невысокой популярности этого вида хирургического вмешательства. И это правда.

Однако вспомнилось былое. Во второй половине 80-х годов прошлого века мы получили патент на медиальный и латеральный эндопротез мыщелков голени (патент № 1757661 AISU, A61F2/38 Эндопротез коленного сустава Агаджанян В.В., Ахмедов Б.А. (СССР): Кузбасский научноисследовательский институт травматологии и реабилитации - 4856315/14; заявлено 08.06.90 Опубл.30.08.92. Бюл. № 32).

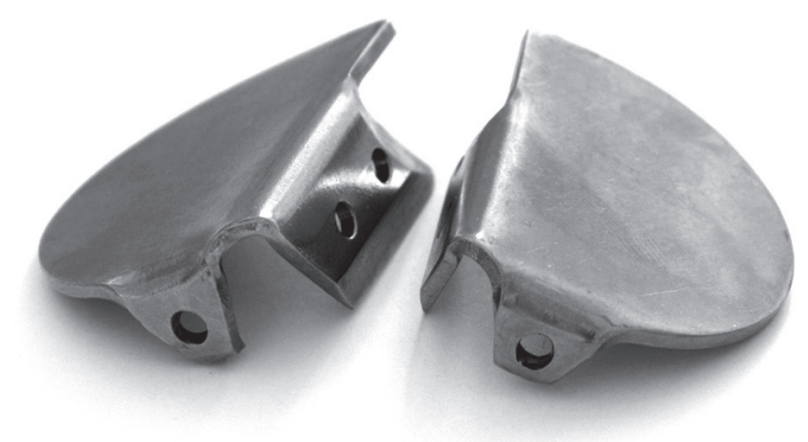

Во время разработки эндопротеза возникало много вопросов, в частности пара трения металл (титан) и хрящевая ткань мыщелков бедра. Но мы опирались на опыт использования однополюсного эндопротеза тазобедренного сустава Мура-ЦИТО, где также использовалась пара трения металлхрящ. Наблюдения за больными настроили нас на оптимистический лад.

Прошло много лет, и отсутствие документации, к сожалению, не позволяет сейчас представить точные данные. Нами было прооперировано около 30 пациентов с гонартрозами. Через год-два у 3 или 4 пациентов трансплантаты были удалены. Основная причина - нестабильность эндопротеза и дискомфорт. Мы обратили внимание, что на поверхности металла образовалась фибриновая пленка, по плотности не уступающая хрящевой ткани. Конец 80-х и 90-е годы прошлого столетия внесли сумятицу в развитие многих отраслей, и наши идеи погибли в тумане времени. Но недавно к нам обратился пациент по поводу дискомфорта и боли в коленном суставе. Выяснилось, что это один из пациентов с нашим эндопротезом. Он ходил с ним 30 лет. Эндопротез был удален, произведена синовэктомия. Но это уже история.

Наше мнение: необходимо развивать одномыщелковое эндопротезирование, конечно, тщательно подбирая показания. Это малотравматичная операция несет меньшую угрозу развития инфекционных осложнений, чем тотальное эндопротезирование, когда после удаления протеза в большинстве случаев необходимо выполнять артродезирование.

В медицине все новое сначала - «горе от ума», потом это забывается.

Мы желаем авторам публикации дальнейших исследований и успехов в этом направлении.

Агаджанян Ваграм Ваганович

д-р мед. наук, профессор, академик РАЕН, Заслуженный врач РФ, советник главного врача ГАУЗ «Кузбасский клинический центр охраны здоровья шахтеров», г. Ленинск-Кузнецкий, Россия

Ахмедов Багавдин Абдулгаджиевич д-р мед. наук, заведующий отделением ортопедии и травматологии НМИЦ хирургии им. А.В. Вишневского, г. Москва, Россия 